\title{
Distribution and population densities of selected uncommon bird species in Zambezi riparian forest, NE Namibia
}

\author{
Grzegorz Kopij \\ Department of Integrated Environmental Science, Ogongo Campus, University of Namibia \\ Private Bag 5520 Oshakati, Namibia \\ E-mail:g.kopij@unam.na
}

A territory mapping method has been employed in 2015 to assess the population density of 8 non-passerine and 10 passerine uncommon bird species breeding in a peri-urban riparian forest ( $280 \mathrm{ha}$ ) along Zambezi River (7 km long) near Katima Mulilo NE Namibia. The population densities (pairs per $100 \mathrm{ha}$ ) are estimated as follows: Trumpeter Hornbill: 1.4, Schalow's Turaco: 2.9, Green-backer Heron: 1.1, Little Bittern: 0.4, Lesser Jacana: 0.4, African Finfoot: 0.4, White-crowned Lapwing: 0.7, Long-billed Crombec: 3.9, Yellow White-eye: 4.3, Scarlet-chested Sunbird: 0.7, African Golden Oriole: 2.9, Black-headed Oriole: 0.7, Violet-backed Starling: 0.7, Pied Wagtail: 8.6, Ashy Flycatcher: 0.4, Black Flycatcher: 0.4, Hartlaub's Babbler: 4.3.

Key word: population densities, Namibia, Bycanistes bucinator, Tauraco schalowi.

\section{Introduction}

In the major ornithological works, data on population density for most African bird species are limited, especially data on population densities of less common species from larger study plots, representative enough to make reliable estimations (Fry et al. 1982-2004; Del Hoyo et al. 1992-2013; Hockey et al. 2005). To make the matter even worse, most data on population densities (breeding populations) of African birds refer to the number of individuals per ha (cf. Hockey et al. 2005). However, in population studies the breeding pair is the census unit, not an individual, (Sutherland 1996, Bibby et al. 2012). Data referring to the number of breeding individuals (and in addition from so small study plots) have limited significance in population ecology. There is therefore an urgent need to fill this gap in study of ecology of African birds. The presented paper provides data on population densities (based on the number of breeding pairs) of selected uncommon bird species occuring in poorly studied and remote habitat in southern Africa.

\section{Material and methods}

\section{Study area}

The study area was located in the Zambezi Valley near Katima Mulilo in the Zambezi Region, NE Namibia. The study area comprised a forest stretching between the river and the international road from Zambia (Wenela Bridge on Zambezi) through Katima Mulilo to Botswana (Ngoma Bridge on Chobe), laying on the left bank between the Winela Bridge and the Zambezi River Lodge. It is $7 \mathrm{~km}$ long and $200-700 \mathrm{~m}$ wide (400 $\mathrm{m}$ on average). The approximate surface area of our study is 280 ha.

The natural vegetation in the study area is classified as Riparian Zambezi Forest (Mendelsohn et al. 2009). It is composed of large trees such as African Teak Pterocarpus angolensis, Albizias Albizia spp., Apple Leave Lonchocarpus nelsii, Baobab Adansonia digitata, Burkea Burkea africana, Combretum Combretum spp., Camel-thorn Acacia erioloba, Corkwoods Commiphora spp., False Mopane Guibourtia coleospermum, Jackal Berry Diospyros mespiliformis, Knob-thorn Accacia nigrescens, Makalani Palm Hyphaene petersiana, Manketti Schinziophyton rautanenii, Marula Sclerocarya birrea, Mopane Colophospermum mopane, Pod Mahogany Afzelia quanzensis, Silver Cluster-leaf Terminalia sericea, Sausage Tree Kigelia africana, Sycomore Fig Ficus sycomorus, White Bauhinia Bauhinia petersiana, Zambezi Teak Baikiaea plurijuga(Kopij 2016).

The forest is interlaced with pans covered with grass and sedges flooded almost on yearly basis. About $25 \%$ of the land is converted into arable and built-up areas, but large trees usually remain even in these transformed areas. 
The mean annual temperature for Katima Mulilo is $21^{\circ} \mathrm{C}$. Average maximum temperature during the hottest month (September) is $35^{\circ} \mathrm{C}$; the average minimum temperature during the coldest month (July) is $3^{\circ} \mathrm{C}$. In the most humid month (February) the humidity is $80-90 \%$, and only $10-20 \%$ in the least humid month (September). The average annual rainfall is $700 \mathrm{~mm}$, and it is the highest in Namibia (Mendelsohn et al. 2009). Most of the rains fall between November and March. Both in 2015 and 2016 the annual rainfall was lower than the long-term average, but in 2015 it was much lower (262 mm) than in 2016 (416 mm). (Fig. 1).

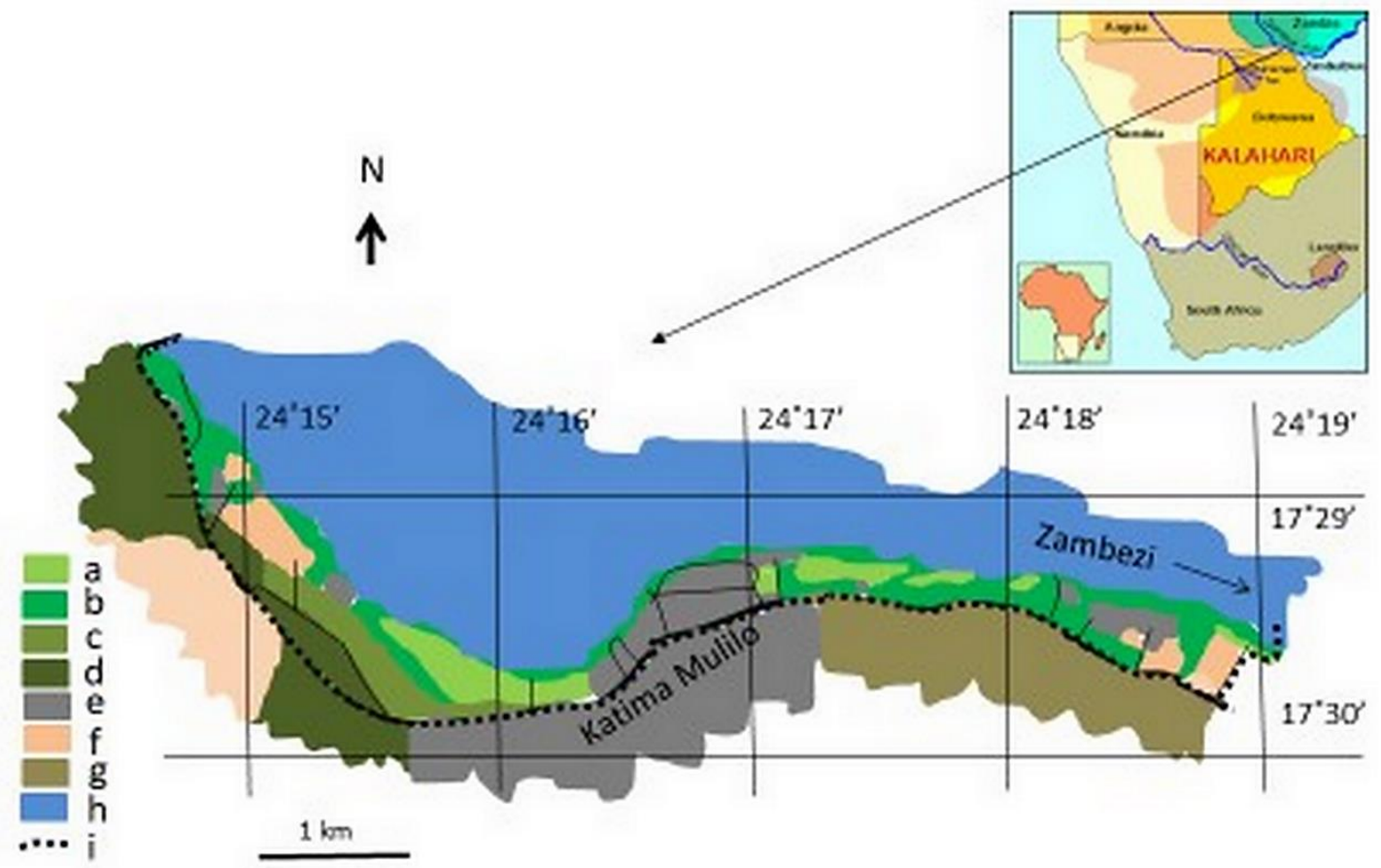

Fig. 1. The study area: Zambezi riparian forest. Explanations: a - grassland, b - Zambezi riparian forest, $c$ - mopane forest, d - Kalahari Woodland, e - urbanized built-up ares, f - arable land, g - rural areas, h - Zambezi River, i - border of the study area.

A territory mapping method (Southerland 1996; Bibby et al. 2012) has been employed to assess the population densities of selected bird species. The study area was divided into six sections. Birds were counted in each of the sections in one morning. So, six mornings were devoted to cover the whole study area. Such complete coverage was achieved four times in 2015, one complete survey was achieved in each of the following months of 2015: August, September, October and November. During each count all individuals of selected bird species seen or heard were plotted on the map 1: 500 . Special attention was paid to birds showing territorial behavior or breeding display. Also records of two or three simultaneously calling males were important in interpreting the results. A bird or pair of the same species recorded at the same site at least in two out of the four month was interpreted as residential/breeding/territorial (following Bibby et al. 2012).

\section{Results and discussion}

Two most interesting species in this study are the Trumpeter Hornbill Bycanistes bucinator and Schalow's Turaco Tauraco schalowi. Four breeding sites of the Trumpeter Hornbill were recorded (Table 1, Fig. 2). In all those sites, they bred co-operatively, i.e. one breeding pair and a few so called helpers (non-breeding). The population density of the Schalow's Turaco was twice higher than that of the Trumpeter Hornbill (Fig. 3); but they were not recorded as breeding co-operatively. In Malawi mountain forest, the Trumpeter Hornbill breeding density was 1.7 pairs per 100 ha (Dowsett-Lemaire 1989); in a coastal forest in the Eastern Cape, South Africa - 3 pairs per 100 ha (Hockey et al. 2005). The densities were, therefore, similar to these recorded in Zambezi forest.

A few water bird species were recorded breeding on the river bank: I counted four breeding sites of the Greenbacked Heron Butorides striatus; we recorded three pairs of the Black Crake Amaurornis flavirostris, two pairs of the Whitefroneted Lapwing Vanellus albiceps, single pairs of the Finfoot Podica senegalensis, Lesser Jacana Microparra capensis and Little Bittern Ixobrychus minutus (Table 1, Fig. 4 and 5).

On protruding rocks in the rapids on Zambezi River close to the Wenela Bridge, a breeding colony of the Rock Pratincole Glareola nuchalis was recorded, with 5-10 pairs in 2015. The population densities of all these water bird species 
could be, however, underestimated, due to their elusiveness and seclusion. Except for kingfishers, no other water bird species were recorded breeding in this area in 2015.

Table 1. Population densities of selected bird species in a Zambezi forest (280ha).

\begin{tabular}{llll}
\hline Species & $\begin{array}{l}\text { Number of } \\
\text { pairs }\end{array}$ & $\begin{array}{l}\text { Density } \\
\text { (pairs/100 ha) }\end{array}$ & $\begin{array}{l}\text { Density } \\
\text { (pairs/10 km) }\end{array}$ \\
\hline Non-passerines & & 1.4 & 5.7 \\
Trumpeter Hornbill & 4 & 2.9 & 11.4 \\
Schalow's Turaco & 8 & 1.1 & 4.3 \\
Green-backed Heron & 3 & 0.4 & 1.4 \\
Little Bittern & 1 & 1.1 & 4.3 \\
Black Crake & 3 & 0.4 & 1.4 \\
Lesser Jacana & 1 & 0.4 & 1.4 \\
African Finfoot & 1 & 0.7 & 2.9 \\
White-crowned Lapwing & 2 & & \\
\hline Passerines & & 3.9 & 15.7 \\
Long-billed Crombec & 11 & 1.1 & 4.3 \\
Yellow White-eye & 3 & 0.7 & 2.9 \\
Scarlet-chested Sunbird & 2 & 2.9 & 11.4 \\
African Golden Oriole & 8 & 0.7 & 2.9 \\
Black-headed Oriole & 2 & 0.7 & 2.9 \\
Violet-backed Starling & 2 & 2.1 & 8.6 \\
Pied Wagtail & 6 & 0.4 & 1.4 \\
Ashy Flycatcher & 1 & 0.4 & 4.3 \\
Black Flycatcher & 1 & 1.1 & \\
Hartlaub's Babbler & 3 & & \\
\hline
\end{tabular}

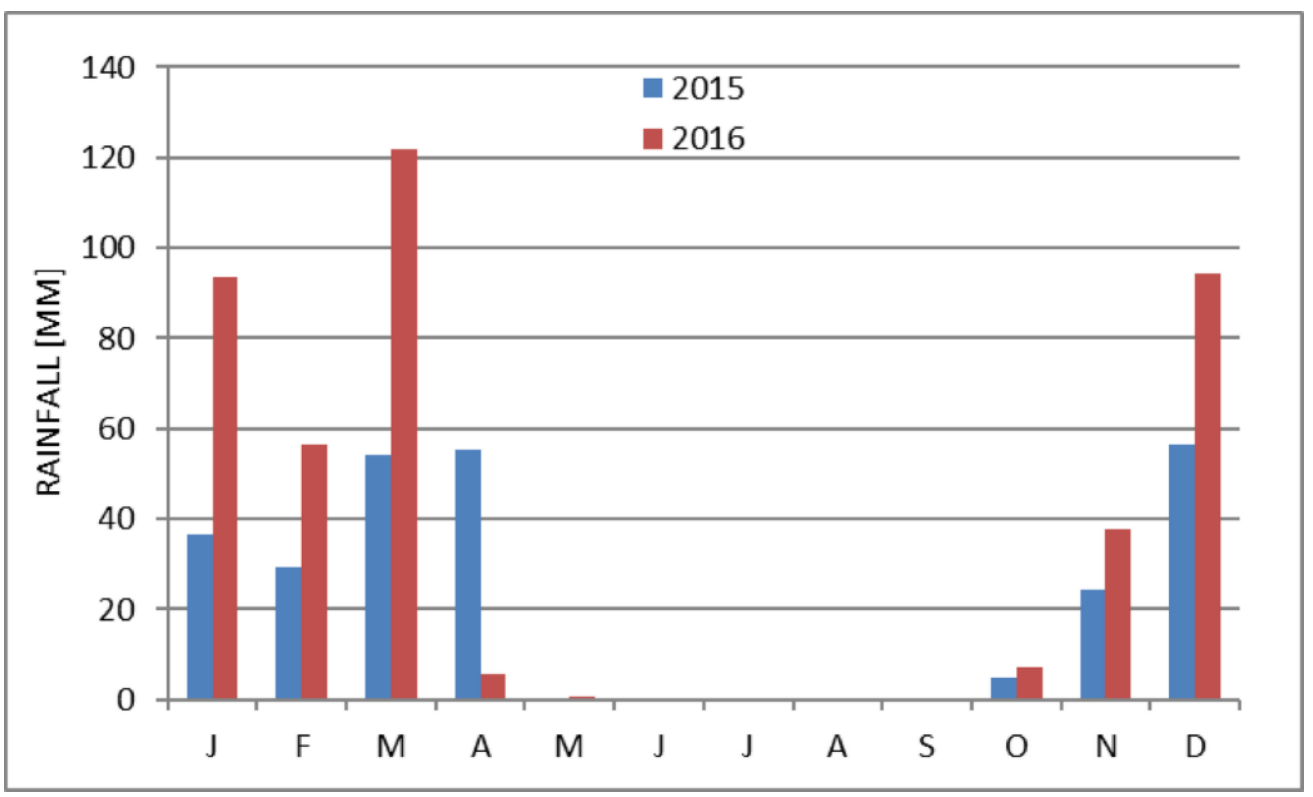

Fig. 2. Monthly rainfall in Katima Mulilo in 2015 and 2016. 


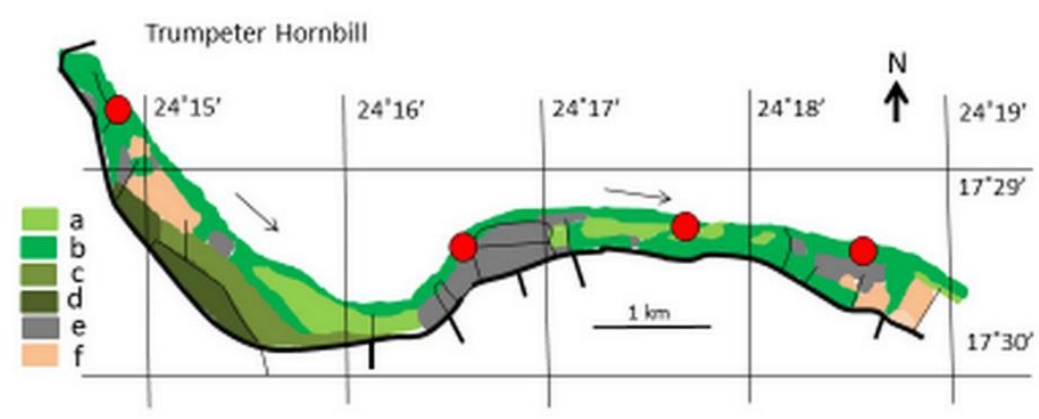

Fig. 3. Distribution of breeing pairs (co-operatively breeding) of the Trumpeter Hornbill in Zambezi riparian forest.

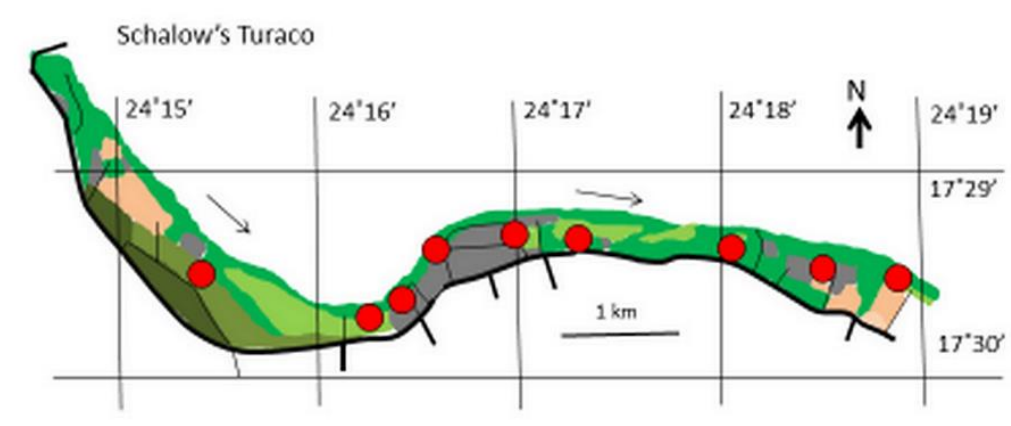

Fig. 4. Distribution of breeding pairs of the Schalow's Turaco in Zambezi riparian forest.

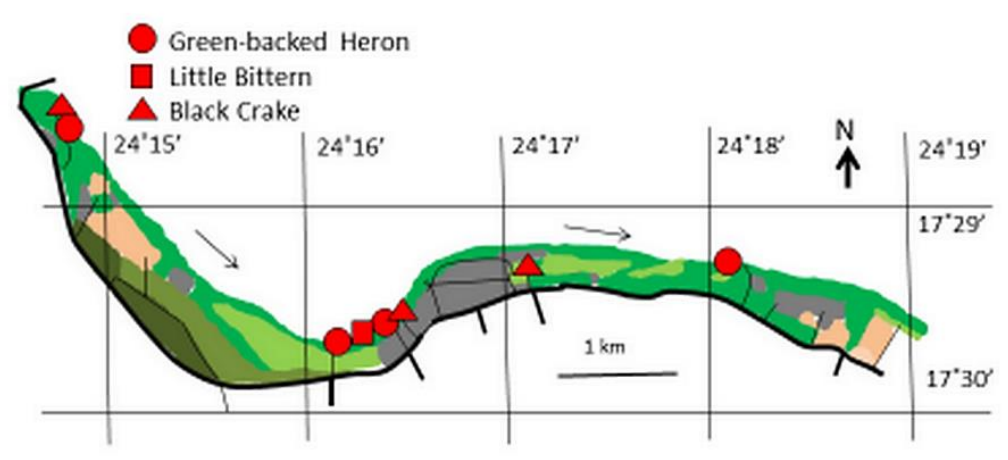

Fig. 5. Distribution of breeding pairs of the Green-backed Heron, Little Bittern and Black Crake in Zambezi riparian forest.

The Long-billed Crombec Sylvietta rufescens nested in the Zambezi riparian forest at a density of 3.9 pairs per 100 ha (Table 1, Fig. 6). In dry forests in Botswana it was 17-20 pairs per 100 ha (Harrison 1997), and similar (18.3 pairs per 100 ha) in Baikiaia Kalahari Woodland in Zambezi Region, NE Namibia (Kopij 2017). The density in dry woodlands was therefore much higher than in riparian forest. In other regions of southern Africa, in wet savanna or forests, the population density was similar to that recorded in Zambezi riparian forest, e.g.: 2.0 pairs per 100 ha in Mopane Savanna in Cuvelai Drainage System, N Namibia (Kopij 2018a); or 3.0 pairs per 100 ha in a mixed woodland in Zimbabwe (Vernon 1985) and in riparian forest on the Chobe River in Kasane, NE Botswana, the Long-billed Crombec was not recorded at all (Kopij $2018 \mathrm{~b})$. 


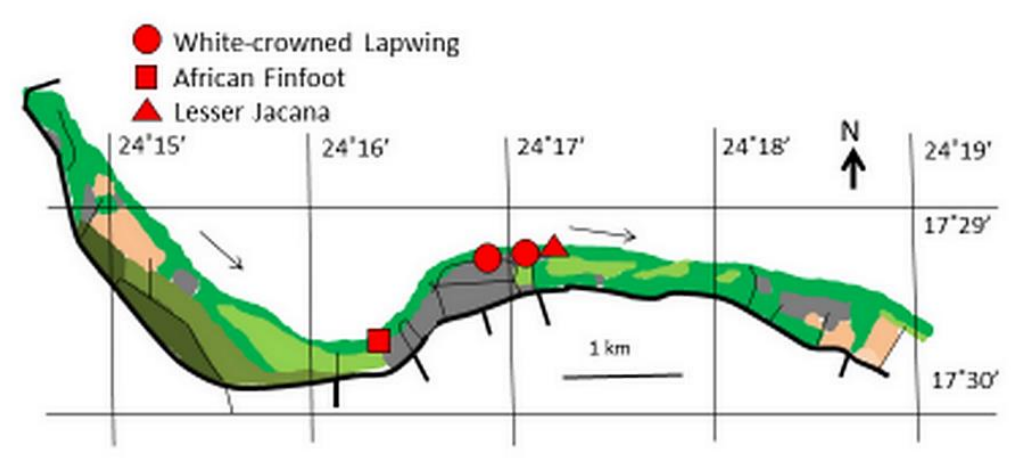

Fig. 6. Distribution of breeding pairs of the White-crowned Lapwing, African Finfoot and Lesser Jacana in Zambezi riparian forest.

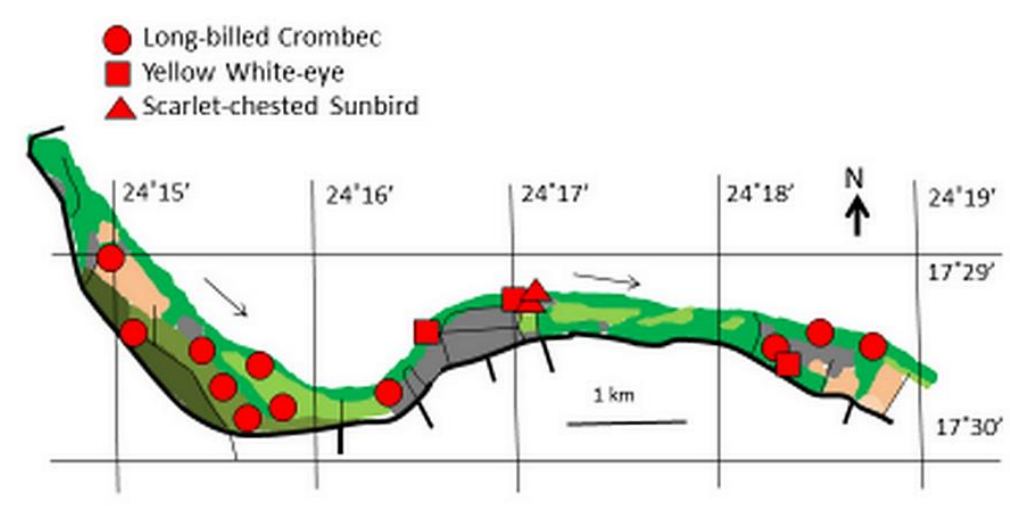

Fig. 7. Distribution of breeding pairs of the Long-billed Crombec, Yellow White-eye and Scarlet-chested Sunbird in Zambezi riparian forest.

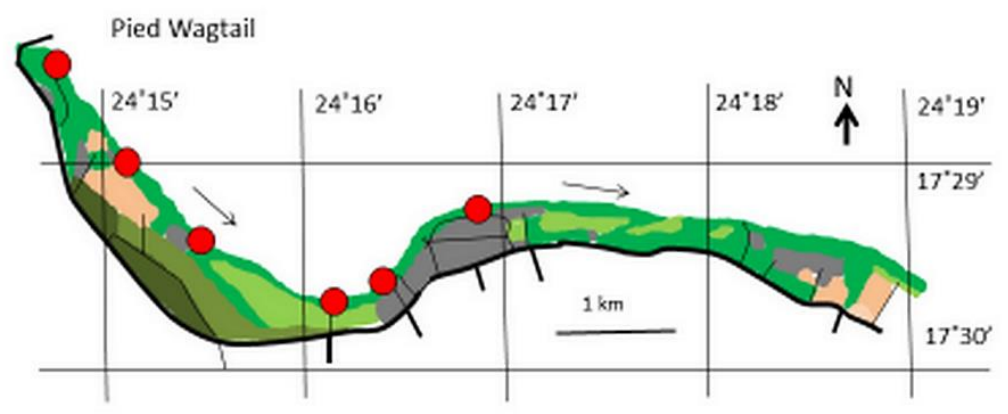

Fig. 8. Distribution of breeding pairs of the Pied Wegtail in Zambezi riparian forest.

Three pairs of the Yellow White-eye Zosterops senegalensis and two pairs of the Scralet-chested Sunbird Chalcomitra senegalensis were also recorded (Table 1, Fig. 6).

The Pied Wagtail Motacilla aguimp nested in a density of 2.1 pairs per 100 ha in the riparian forest, or 8.6 pairs per $10 \mathrm{~km}$ of one river bank (Table, Fig. 7). Along Zambezi River between Kariba and Chirundu the population density was estimated at 20 pairs per $10 \mathrm{~km}$, and along the Orange River in the Northern Cape, South Africa - 12 pairs per $10 \mathrm{~km}$ on both banks (Allan, Jenkins 1993).

Two oriole species, the African Golden Oriole Oriolus auratus and Black-headed Oriole Oriolus larvatus were recorded (Table 1, Fig. 8). The former species nested at much higher density (2.9 pairs per 100 ha) than the later one (0.7 pair per 100 ha). Two Violet-backed Starling breeding pairs were also recorded (Table 1, Fig. 8). 


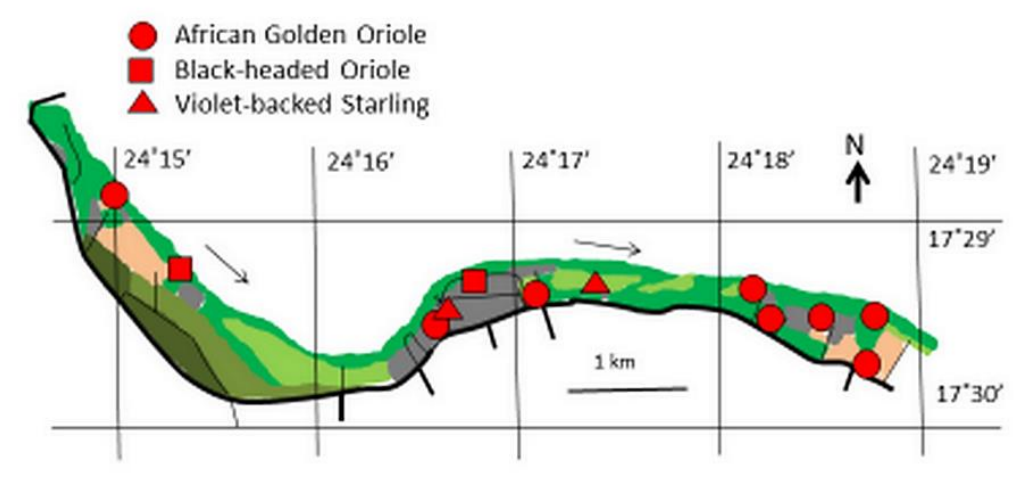

Fig. 9. Distribution of breeding pairs of the African Golden Oriole, Black-headed Oriole and Violet-backed Starling in Zambezi riparian forest.

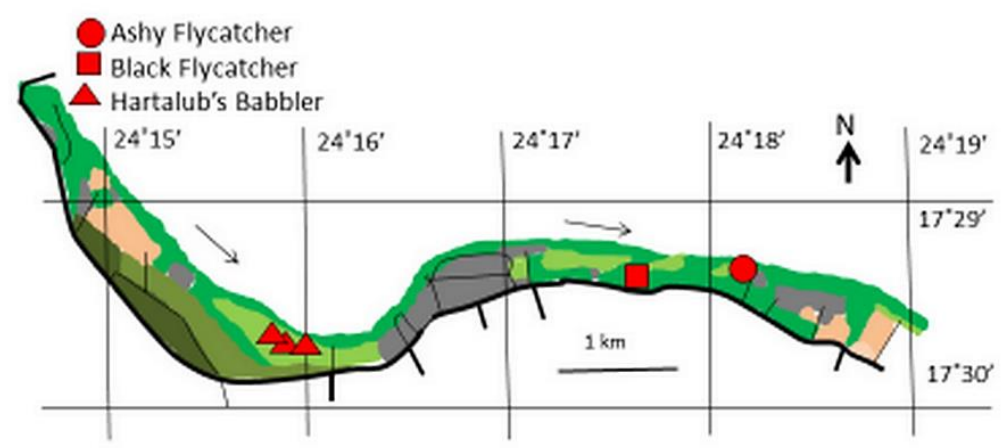

Fig. 10. Distribution of breeding pairs of the Ashy Flycatcher, Black Flycatcher and Hartlaub's Babbler in Zambezi riparian forest.

Only single pairs of the Southern Black Flycatcher Melaenornis pammelaina and the Ashy Flycacher Muscicapa caerulescens and three pairs of the Hartlaub's Babbler Turdoides hartlaubii (co-operative breeding) were also recorded as breeding residents in the riparian forest.

It should be pointed out that the mapping method could underestimate the number of some elusive species like African Finfoot, Little Bittern, and Ashy Flycatcher. On the other hand, Schalow's Tauraco, Trumpeter Hornbill, and African Golden Oriole are quite vocal, active, large, colorful, and conspicuous, so their population densities were estimated accurately and precisely.

Since the study area is very close to the UNAM Department of Wildlife, and to Ktima Mulilo town, it can be an ideal place to monitor changes in the population densities of these selected species. Such monitoring program is of special significance, as this riparian forest is a marginal habitat in Namibia and under serious threat of degradation. Some bird species may adapt to these changes, but other will decline or may disappear from this habitat. Birds can, therefore, be used as sensitive bioindicators of any negative changes in this forest. Urban planners, members of the regional council and nature conservation agencies should undertake alternative measurers to prevent such destruction of this unique habitat.

\section{References:}

Allan DG, Jenkins AR. 1993. A count of waterbirds along a section of the lower Orange River. Bontebok 8: 33-34.

Bibby CJ, Burgess ND, Hill DA. (2012). Bird censuses techniques. London: Academic Press.

Del Hoyo J, Elliott A, Sergatal J, Chrisie DA. (eds.). 1992-2013. Handbook of the Birds of the World. Vol. 1-13. Barcelona, Lunx Edicions.

Dowsett-Lemaire F. 1988. Fruit choice and seed dissemination by birds and mammals in the evergreen forest of upland Malawi. Rev. d'Ecol. (Terre et Vie) 43: 251-283.

Fry CH, Stuart K, Urban E. 1982-2004. The birds of Africa. Vol. 1-7. Cambridge (MA, USA): Academic Press.

Harrison JA. 1997. Longbilled Crombec. In: Harrison JA. et al., editors. The Atlas of Southern African Birds. p. 266-267.

Hockey PAR, Dean WRJ, Ryan PG, Maree S. (eds.) 2005. Roberts' Birds of Southern Africa. Cape Town: John Voelcker Bird Book Fund. 
Kopij G. 2016. Birds of Katima Mulilo town, Zambezi Region, Namibia. International Science \& Technology Journal of Namibia 7: 85-102.

Kopij, G. 2017. Structure of avian assemblages in Zambezian Baikiaeae woodlands, northern Namibia. Zoology \& Ecology 27: 1-10.

Kopij G. 2018a. Breeding bird community of Ogongo Game Reserve, north-central Namibia. International Science \& Technology Journal of Namibia 12: 117-126.

Kopij G. 2018b. Atlas of birds of Kasani. Babbler 64: 3-15.

Mendelsohn J, Jarvis A, Roberts C, Robertson T. 2009. Atlas of Namibia. A Portrait of the Land and its People. Cape Town: Sunbird Publishers.

Sutherland WJ. 1996. Ecological Census Techniques: a handbook. Cambridge (U.K.): Cambridge University Press.

Vernon C.J. 1985. Bird populations in two woods near Lake Kyale. Honeyguide 31: 148-161.

\section{Citation:}

Grzegorz K. 2019. Distribution and population densities of selected uncommon bird species in Zambezi riparian forest, NE Namibia. Acta Biologica Sibirica 5(4): 5-11.

Submitted: 12.10 .2019 . Accepted: 21.11 .2019

cross ref http://dx.doi.org/10.14258/abs.v5.i4.6724 